\title{
Involving men
}

Population Council

Follow this and additional works at: https://knowledgecommons.popcouncil.org/ series_newsletters_momentum How does access to this work benefit you? Let us know!

\section{Recommended Citation}

"Involving men," Momentum newsletter. New York: Population Council, 2011. 

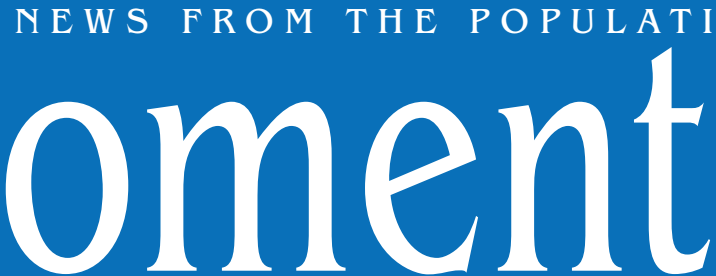

C O U N C I L
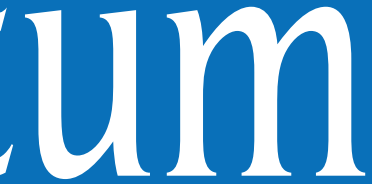

NOVE M B E R 2011

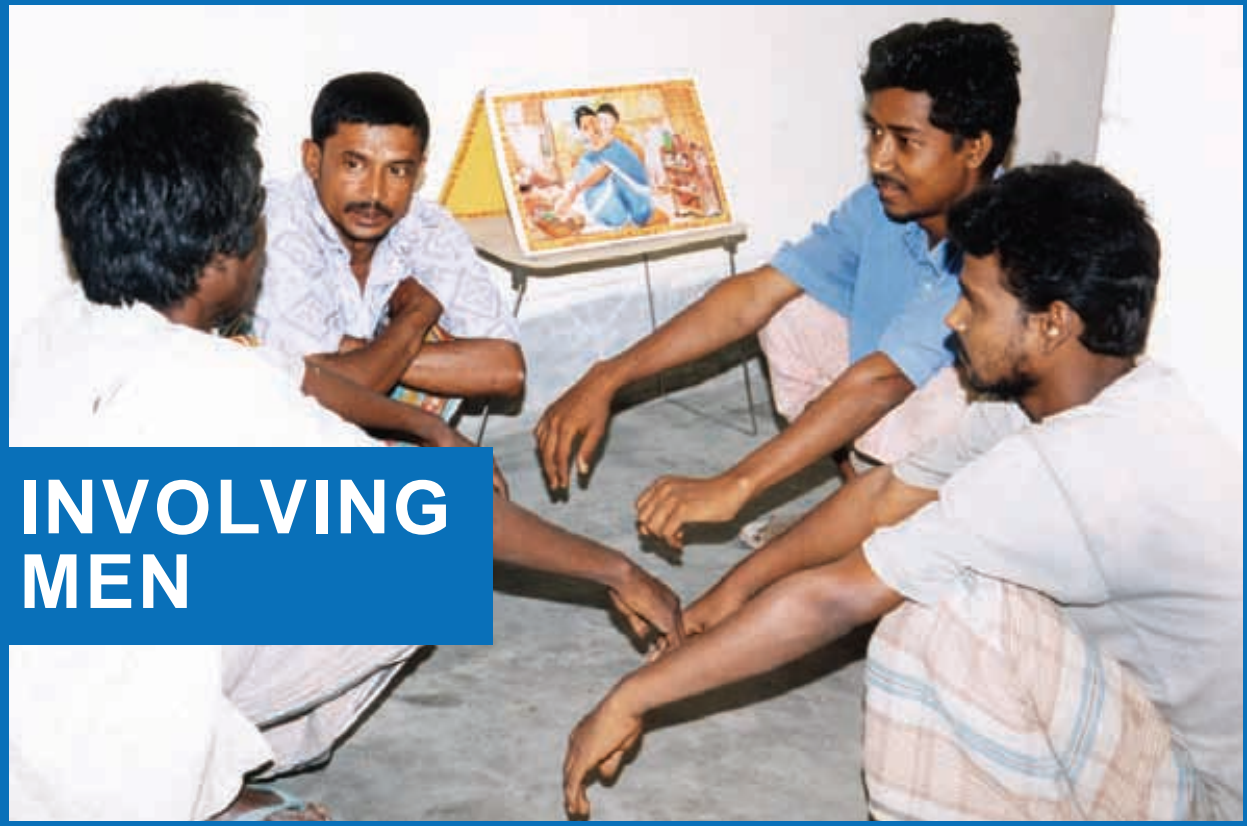

Participants in a Bangladeshi program to strengthen sexual health services for men.

\section{IN THIS ISSUE:}

POPULATION COUNCIL PRESIDENT DISCUSSES PROGRAMS FOR MEN HELPING HUSBANDS SAFEGUARD HEALTH IN ETHIOPIA

CALLING ATTENTION TO GENDER NORMS AND RIGHTS

IDENTIFYING NEW MALE CONTRACEPTIVES

ACHIEVING SCALE FOR MALE CIRCUMCISION SERVICES

WORKING TO BAN FEMALE GENITAL MUTILATION/CUTTING

PROFILES: SAM KALIBALA, KENYA COUNTRY DIRECTOR, AND JEFFREY PASSEL, FORMER COUNCIL FELLOW 
CONSIDER THESE NUMBERS:

\section{MORE THAN 2/3}

OF MEN AGED 15-19 SURVEYED IN BENIN, ETHIOPIA, GABON, MALAWI, UGANDA, AND ZIMBABWE WHO HAVE NEVER BEEN TESTED FOR HIV SAY THEY WOULD LIKE TO BE.

LESS $50 /$ OF SEXUALLY ACTIVE MEN THAN 10 AGED 15-24 SURVEYED IN UGANDA WHO HAD A SEXUALLY TRANSMITT INFECTION IN THE PAST 12 MONTHS INFORMED THEIR PARTNERS.

LESS $50 /$ OF SEXUALLY ACTIVE THAN $\bigcirc 0$ MEN AGED 15-24 IN MOST COUNTRIES USE A CONTRACEPTIVE METHOD OR RELY ON THEIR PARTNER'S METHOD.

\section{LESS THAN 50\%}

OF MEN SURVEYED IN RURAL AREAS OF CHAD, GUINEA, MALI, MOZAMBIQUE, AND NIGER KNEW OF A SOURCE FOR OBTAINING CONDOMS.

0 OF MEN AGED 15-54 IN

00 BANGLADESH KNOW THAT CONDOM USE CAN PREVENT HIVIAIDS.

00 OF MEN AGED 15-54 IN BRAZIL KNOW THAT CONDOM
USE CAN PREVENT HIVIAIDS.
MORE $O 0 /$ OF MEN THAN OU/O SURVEYED GERMANY, MEXICO, AND SPAIN EXPRESSED WILLINGNESS

TO USE A NEW MALE CONTRACEPTIVE.
AVERAGE NUMBER OF CHILDREN DESIRED BY MEN IN:

DEVELOPED
COUNTRIES $\underset{\text { LATIN }}{2} 3$ SUB-SAHARAN $5-8$
AFRICA

\section{$\Rightarrow$}
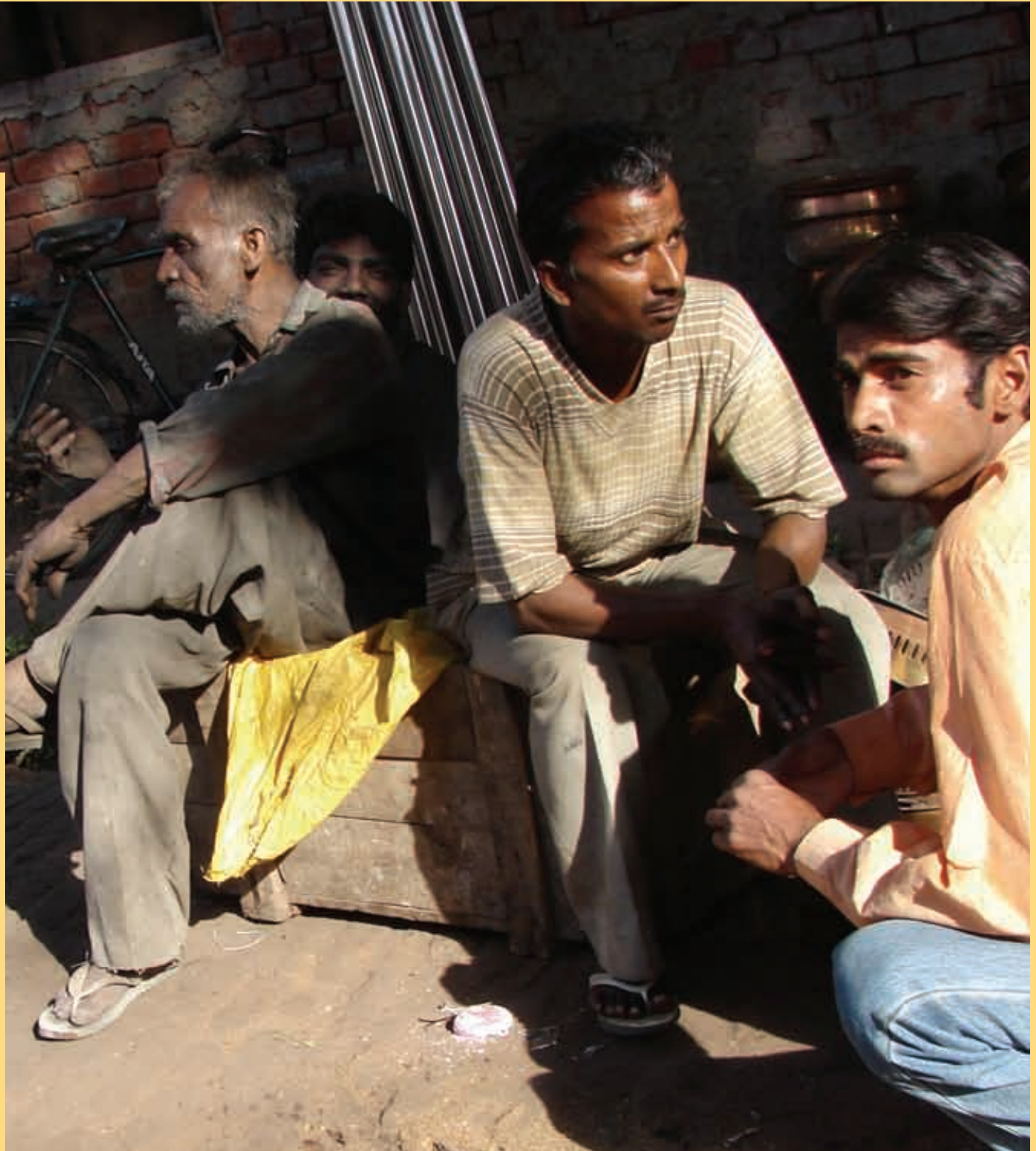
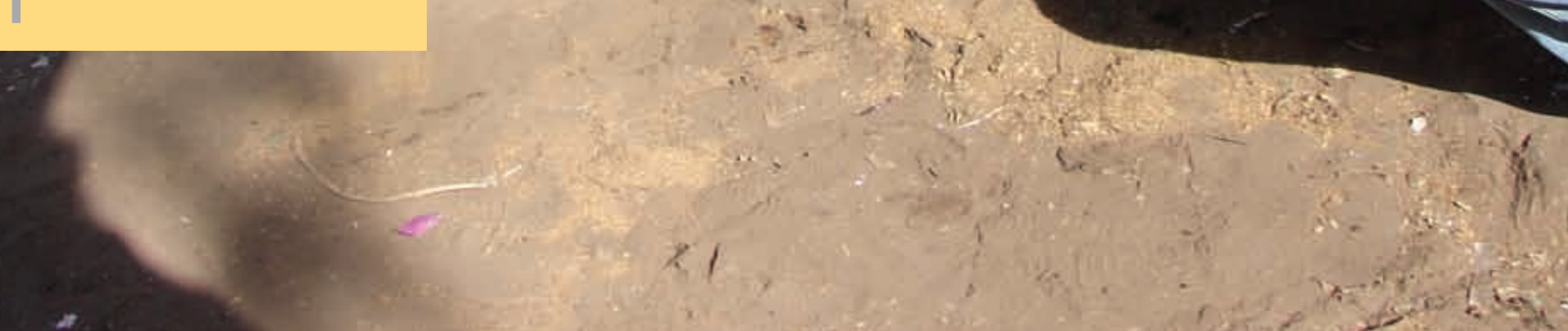


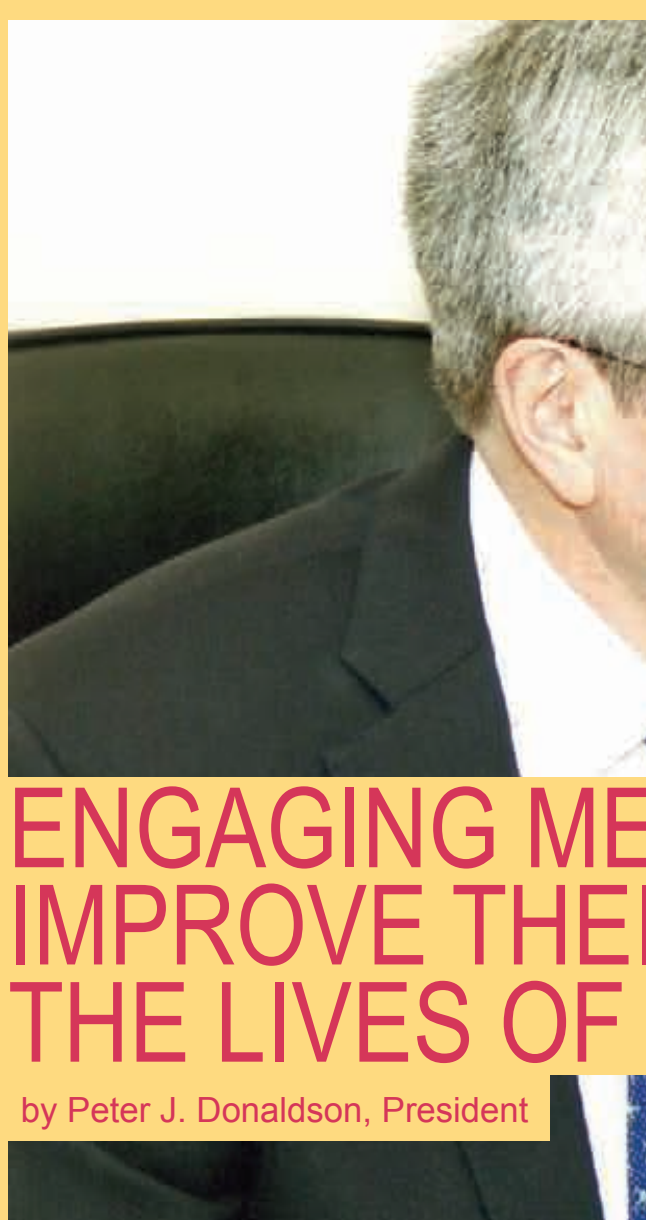

The Population Council's innovative work with men is aimed at improving their lives and the lives of others. One example is our work with African men who have sex with men. In 2000 , few organizations devoted resources to developing services to address the needs of such men. Many African leaders, in fact, denied that they existed. "The [Population Council's] Horizons Program was the first international NGO to recognize that the HIV-related vulnerabilities of men who have sex with men in Africa deserved serious attention," notes Cary Alan Johnson, senior specialist for Africa at the International Gay and Lesbian Human Rights Commission. Our studies showed that African men who risk of HIV infection than the general population, as well as violence, stigma, and discrimination; and that they lack key services. Our research results motivated previously hesitant public health agencies in Kenya, Senegal, and other countries to develop policies and programs to meet the needs of this vulnerable population.

But men who have sex with men are not the only men who benefit from our research and policy change. This issue of Momentum describes some of our other pioneering work involving men. The Council is among

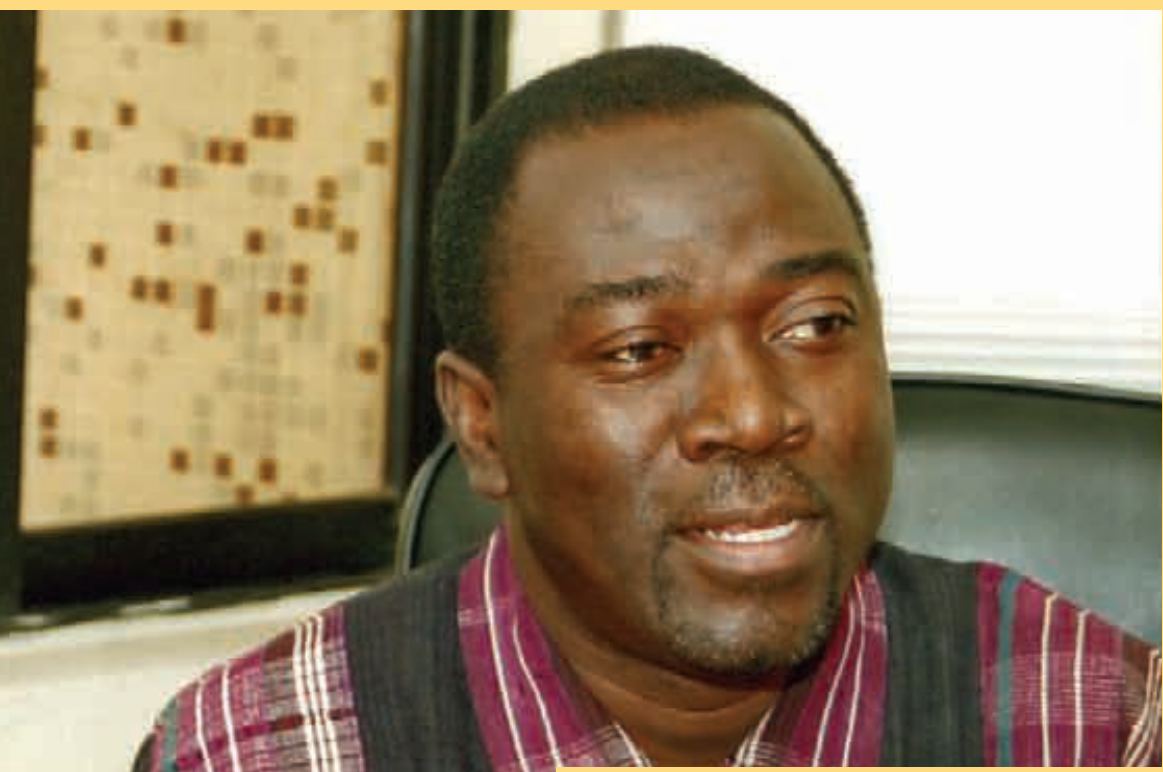

In Nigeria, Council president Peter Donaldson meets with Country Director Babatunde Ahonsi to discuss the Men's Health Network, a project that increases the availability of high-quality HIV counseling and testing and provides prevention services and referrals to care to those most in need.

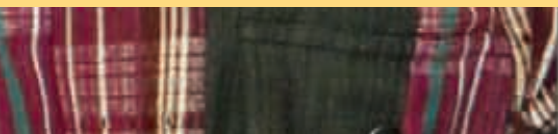

the very few organizations devoting significant resources to developing new contraceptives for men (page 8). We are collaborating to improve the efficiency, effectiveness, and quality of male circumcision services, which are being expanded to reduce HIV transmission in Zambia (page 10). We recently published a ground-breaking curriculum that focuses on the role of gender and rights in sexual health and HIV (page 6). In Ethiopia, we are working with husbands to change rigid gender roles that endanger sexual and reproductive health and well-being (page 4). And in Kenya and Senegal, we are finding the best ways to engage fathers and religious scholars to ban female genital mutilation/ cutting (page 12).

Also in this issue, a former Council Fellow, Jeffrey Passel, describes why the Council's work motivates him to continue to support us. You will also meet Sam Kalibala, Kenya country director, who describes the importance of the Council's research in the fight to halt the spread of HIV in Africa.

Your contribution allows us to develop appropriate and achievable solutions to challenges that would otherwise remain neglected. Thank you for your support. 


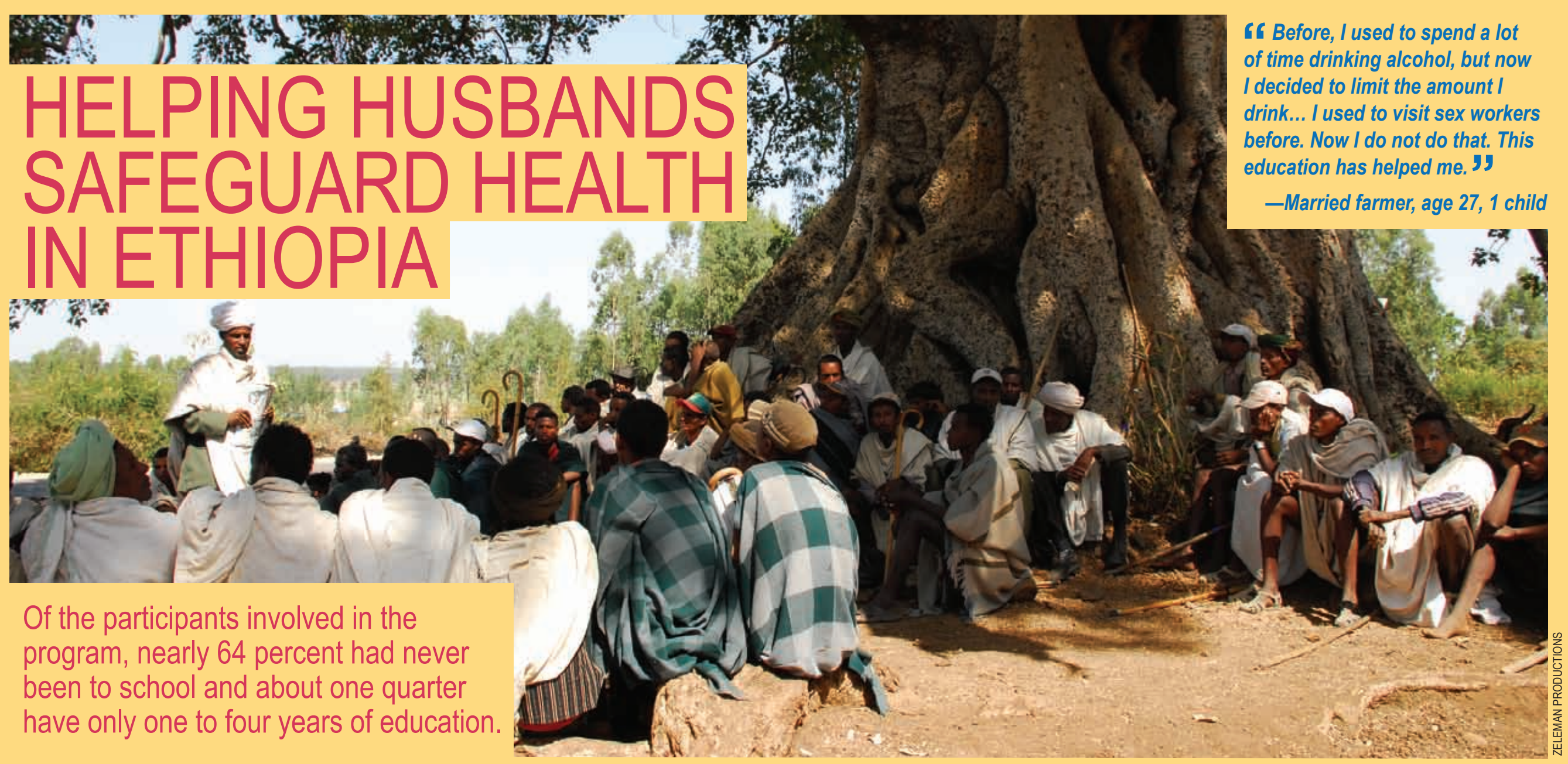

THE PROBLEM In Ethiopia and elsewhere, men are frequently excluded from reproductive health, family planning, and sexuality programs sponsored by governmental and nongovernmental organizations. Surveys among men in Ethiopia suggest that they have low levels of knowledge about reproductive health and that a large number condone violence against women. Recognizing the importance of including men in discussions about family health issues and responding to the stated needs of village men, the Population Council and local partners developed a program for married men in the Amhara region, where HIV prevalence is particularly high.
THE PROGRESS The Addis Birhan (New Light) program promotes HIV prevention by changing men's attitudes through educating husbands about reproductive health, family planning, gender violence, alcohol and drug abuse, and domestic responsibilities. The program began in the Amhara and Tigray regions of Ethiopia, where the vast majority of marriages are arranged and girls are frequently married during childhood. Trained male mentors organize weekly meetings with groups of married men for a period of three to four months. The sessions are held in community settings and promote dialogue, self-exploration, and expression of one's opinions in a nonjudgmental environment. Because the program targets men with very low levels of education, the curriculum includes pictures as teaching aids.

THE IMPACT A midterm evaluation compared men who had participated in the program with those who had not. Husbands participating in the program were less likely to condone domestic violence. Participants were more likely to have assisted with domestic work (78 percent of participants; 59 percent of nonparticipants) and to have fetched water in the past three months ( 75 percent vs. 48 percent). A higher percentage of participants had discussed topics or engaged in joint decisionmaking with their spouses. As a result of the Council's collaboration with the Ministry of Women, Children and Youth, Addis Birhan has reached 90,000 men within two years. The program is currently being adapted for unmarried boys.

DONORS AND PARTNERS Amhara and Tigray Regional Bureaus of Women, Children and Youth Affairs; US Agency for International Development; US President's Emergency Plan for AIDS Relief 


\section{ENCOURAGING}

EDUCATION PROGRAMS THAT CALL ATTENTION TO GENDER NORMS AND RIGHTS

Men who hold chauvinistic attitudes about gender are more likely to abuse their partners, which can lead to higher rates of HIV and other STIs, and to unintended pregnancy.

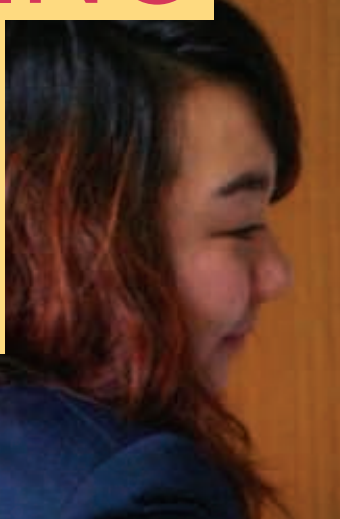

THE PROBLEM Numerous studies have found that young adults who believe that men should be "tough" and should hold more power than women are less likely to use condoms and more likely to have multiple sex partners. Gender inequality and norms profoundly affect the nature and safety of young people's intimate relationships and health. Despite increasing recognition of such findings, many sex and HIV education programs have been slow to update their curricula.

THE PROGRESS In response, the Population Council convened an international working group to develop a user-friendly curriculum-development package based on lessons from successful rights-based, gender-focused programs. The result is It's All One Curriculum, a two-book set available online or in print. It's All One enables curriculum developers, teachers, and community educators to develop locally appropriate sex and HIV education programs that pay special attention to gender and rights, and that foster young people's critical thinking and advocacy skills. It includes eight content units, over 20 fact sheets, and 54 sample activities that use participatory, learner-centered methods.

THE IMPACT Educators worldwide are using It's All One to strengthen curricula. Requests for printed copies have come from 150 countries and from across the US. Laudatory reviews arrive steadily from program managers and researchers. One scholarly review praises its aim to "create a generation of thoughtful, empathetic people who respect their own and others' rights and will be informed and motivated to campaign for change and to take on the challenges presented
If It's All One Curriculum takes us in the direction that sexuality and HIV education should go.

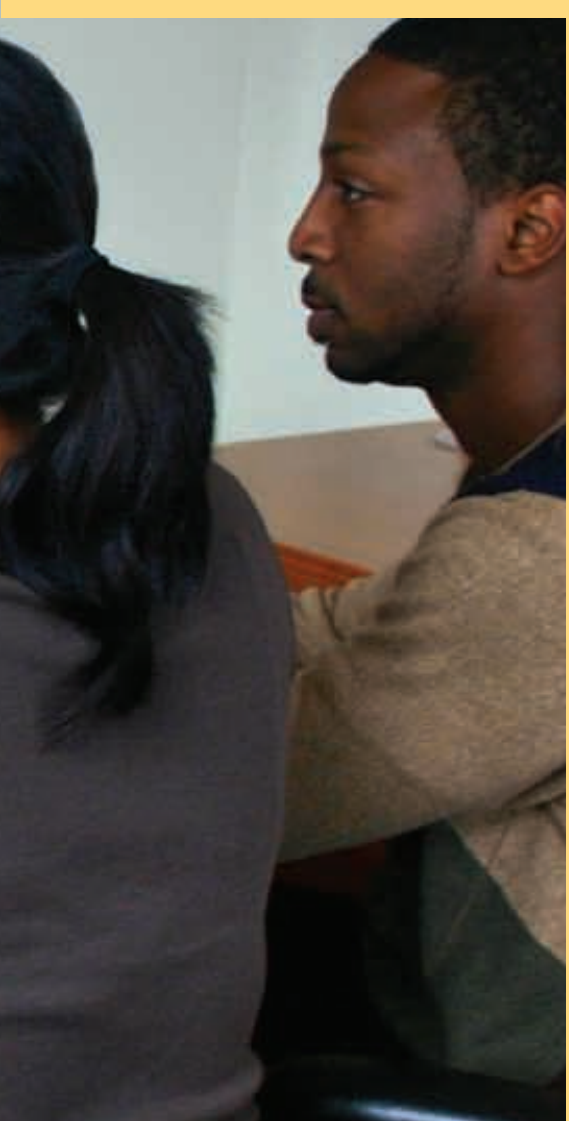

by the global HIV pandemic." A revised edition of It's All One is available in English, French, and Spanish; adaptations are also underway in Bangladesh, China, and Egypt. For more information or to download/ request copies, visit www.itsallone.org.

DONORS AND PARTNERS The Ford Foundation, The William and Flora Hewlett Foundation, The John D. and Catherine T. MacArthur Foundation, UK Department for International Development, The Libra Foundation, United Nations Population Fund, CREA (India), Girls Power Initiative (Nigeria), International Planned Parenthood Federation, International Planned Parenthood Federation (Western national Planned Parenthood Federation (Western
Hemisphere), International Women's Health Coalition, Hundación Mexicana para la Planeación Familiar 

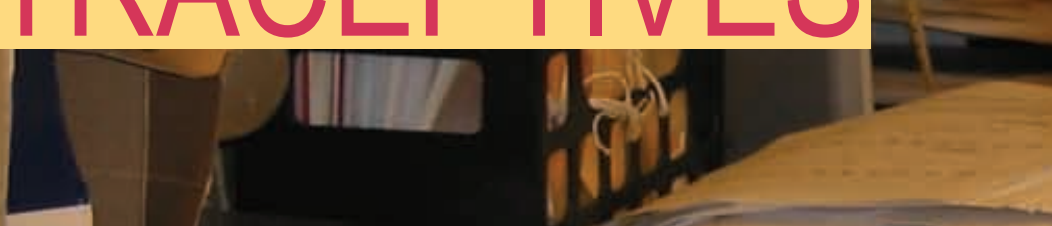

More than half the men consulted in a large-scale study in the US, Europe, Latin America, and Asia reported they would be willing to use a new male method, if available.

THE PROBLEM Contraceptives available to men are limited to condoms, withdrawal, abstinence, and vasectomy. Several studies show that both men and women are interested in more contraceptive choices for men, better engaging men to improve reproductive health.

\section{THE PROGRESS To develop} male contraceptives, researchers at the Population Council's Center for Biomedical Research identify new drugs and delivery devices, collect feasibility and safety data, analyze findings, and submit results to the FDA for approval to conduct safety and efficacy trials in humans. One contraceptive method under development

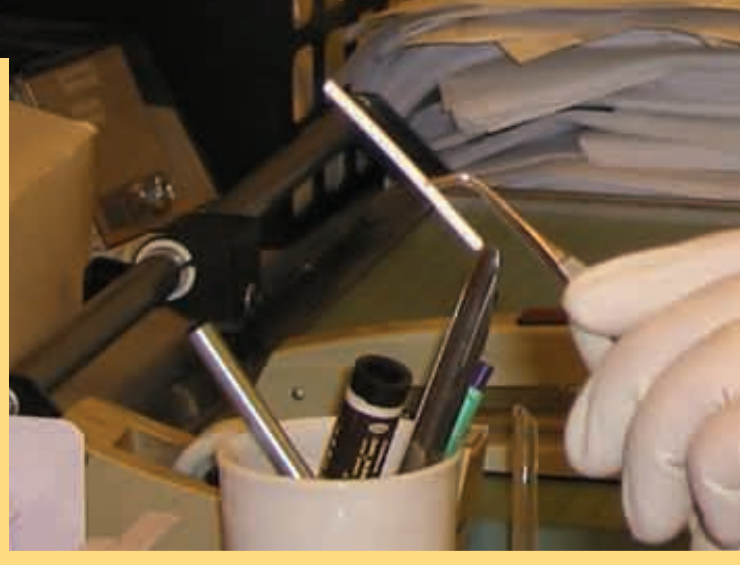

for men is $\mathrm{MENT}^{\circledR}$, a synthetic steroid that resembles testosterone. A MENT implant and transdermal gel and patch formulations are being developed. These products will deliver MENT to suppress sperm cell development without impairing sexual drive, while avoiding side effects.

Other Council studies aim to block sperm production within the testis. Researchers are working to identify the switch that activates sperm so that it can be turned off when contraception is desired or turned on in some cases of male infertility. The Council is also developing a novel approach to male contraception that uses a molecule to
If It's appalling that besides condoms men only have a surgical nonreversible method, $\boldsymbol{y}$ ' says Régine Sitruk-Ware, a reproductive endocrinologist at the Population Council in New York City.

-Scientific American, June 2011 prevent maturation of the sperm, making it unable to fertilize an egg.

THE IMPACT Studies using MENT have shown positive results. A study in men showed that four MENT implants led to significantly reduced sperm count: eight of eleven men had zero sperm count which lasted for several months until the implants were removed. Early studies indicated that MENT gel suppressed steroid sex hormones over a seven-day treatment period, and that the effect was reversible when treatment ended. While MENT is just one possible contraceptive for men, the basic, preclinical, and clinical research and development process has been a critical step in understanding different options for men. More options will give women and men more contraceptive choices, so they can share the responsibility for planning pregnancies and family size.

DONORS The CONRAD Program, The George J. Hecht Fund, The Lita Annenberg Hazen Foundation, The William and Flora Hewlett Foundation, The F.M. Kirby Foundation, Eunice Kennedy Shriver National Institute of Child Health and Human Development, US National Institutes of Health

PARTNERS John Amory (University of Washington, Seattle), Eberhard Nieschlag (University of Munster, Germany), Peter N. Schlegel and Marc Goldstein (Urology, Weill Medical School, Cornell University) Christina Wang (University of California, Los Angeles) 


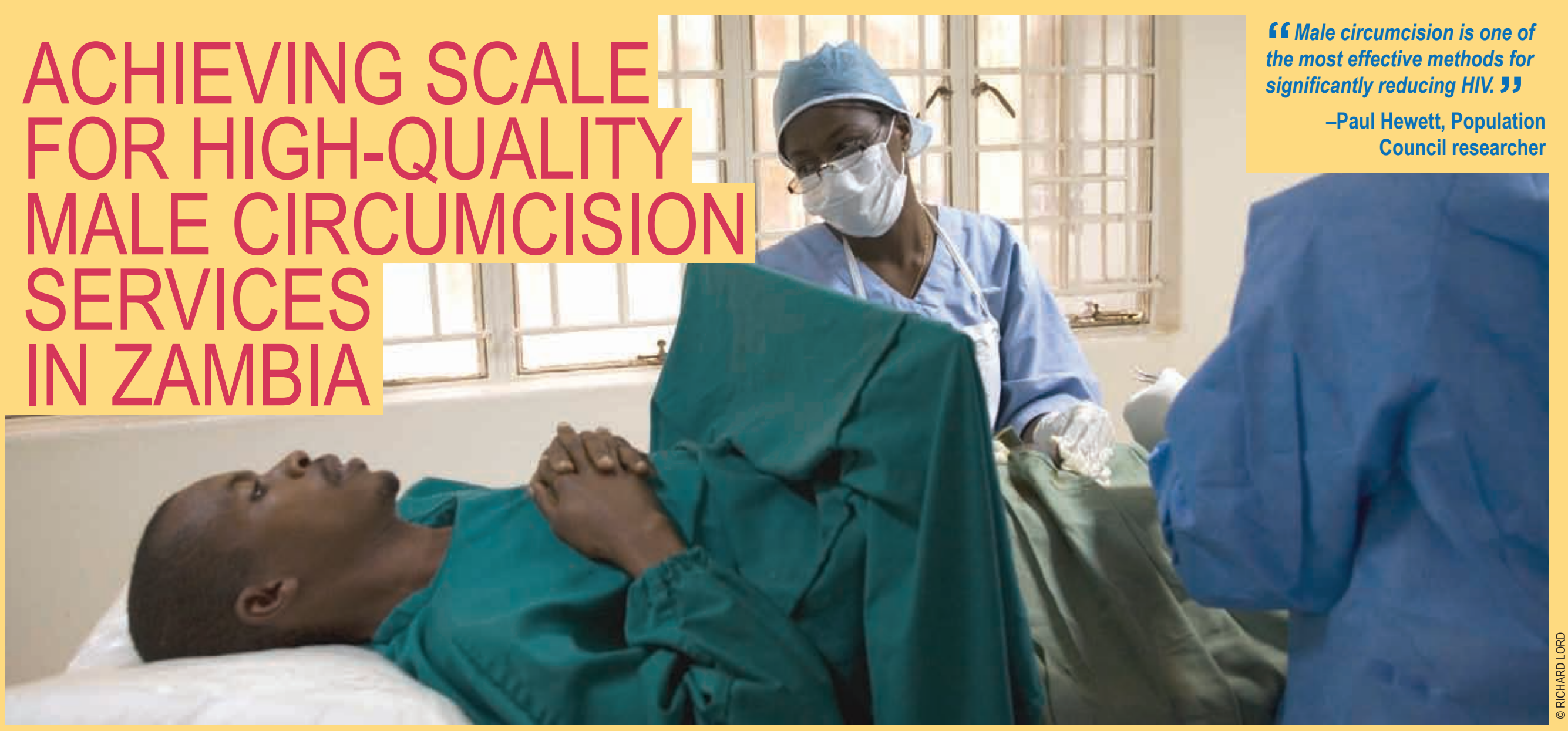

THE PROBLEM In Zambia, 14 percent of adults aged 15-49 live with HIV. Although awareness of HIV and AIDS is nearly universal in the country, use of condoms and other prevention methods remains low. Clinical trials in three sub-Saharan African countries have shown that male circumcision (MC) reduces the risk of female-to-male HIV infection by roughly 60 percent. In urban Zambia, the number of men who do not want to be circumcised is falling slightly; however, in rural areas, aversion to the procedure remains high. Also, even as demand for MC increases, the necessary infrastructure to provide wide-scale and quality services is not in place.
THE PROGRESS A 2006 study led by the World Health Organization suggested that if MC programs were rolled out across sub-Saharan Africa, $\mathrm{MC}$ would have the potential to prevent close to 6 million new HIV infections in the next 20 years. The Population Council is collaborating with three international organizations as part of the "Male Circumcision Partnership" and the Zambian Ministry of Health. The goal of the Partnership is to significantly increase $\mathrm{MC}$ prevalence in Zambia, where only 13 percent of the male population is circumcised. The Council is leading the operations research and evaluation for the Partnership to ensure that services are efficient, effective, and of high quality. The
Council is also conducting a study of postcircumcision behavior to assess whether the benefits of $M C$ are offset by increases in risky behaviors. Based on our research the Council offered recommendations to the Partnership and the Zambian Ministry of Health about expanding outreach messages, enhancing the counseling process, and giving clients the necessary information to make an informed decision about the procedure. These recommendations have been incorporated into a nationwide outreach program.

THE IMPACT Together with the Zambian Ministry of Health, the MC Partnership hopes to reach approximately 50 percent of the adult male population by
2020. The impact of the Zambian program will not remain within its borders. Through the activities and lessons learned of the MC Partnership, other countries scaling MC services can take this program's best practices and implement them as part of their own service models. The scaling up of MC as an HIV prevention strategy in high-prevalence countries will result in an even greater global impact, with the potential for preventing millions of new HIV infections.

DONORS AND PARTNERS The U.S President's Emergency Plan for AIDS Relief Sub grant from Population Services International funded by the Bill \& Melinda Gates Foundation, Marie Stopes International, Jhpiego, and the Zambian Ministry of Health 

FATHERS AND RELIGIOUS SCHOLARS 1 TO BAN FGM/C

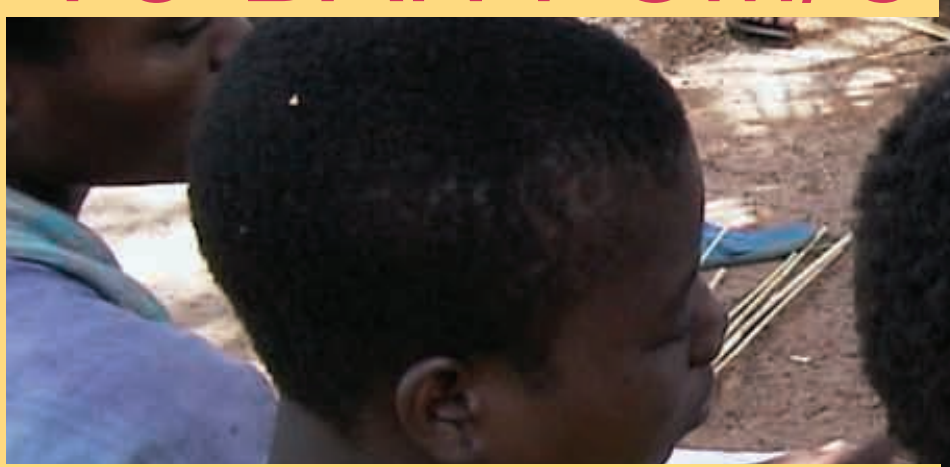

Female genital mutilation/cutting can cause physical and psychological trauma and lifethreatening difficulties during childbirth.

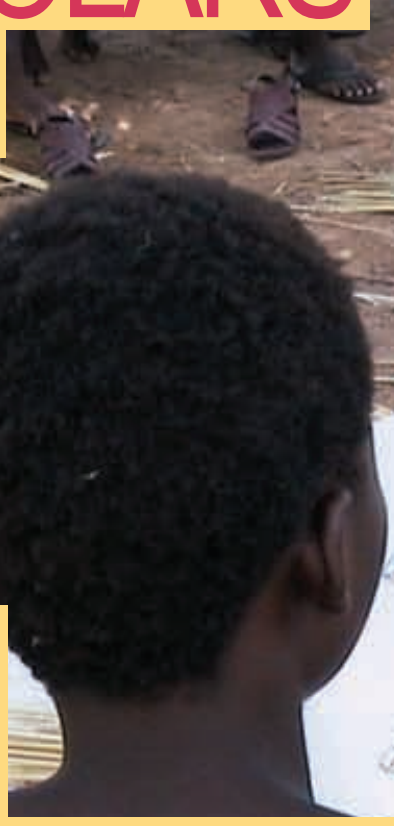

THE PROBLEM Female genital mutilation/cutting (FGM/C) includes cutting, removing, and sometimes sewing up external female genitalia. The World Health Organization (WHO) estimates that between 100 million and 140 million girls and women worldwide have undergone $\mathrm{FGM} / \mathrm{C}$ and that 3 million girls in Africa are at risk each year. According to WHO, FGM/C violates the rights of children; a person's right to health, security, and physical integrity; and the right to be free from torture and cruel treatment.

THE PROGRESS Many people believe that their religion encourages $\mathrm{FGM} / \mathrm{C}$. Religious scholars, usually influential men, can be instrumental in clarifying these beliefs. These leaders and other decisionmakers, including fathers, benefit from participating in community discussions to help end FGM/C. In Kenya, where $\mathrm{FGM} / \mathrm{C}$ prevalence is $97.5 \%$ among the Somali population living in the country, the Population Council and its partners brought together religious scholars to debate the correct position of this practice within Islam and to include this information in their religious teachings. In Senegal, the Council collaborated with Tostan, a nongovernmental organization, to evaluate the impact of an education program that works closely with male religious leaders. In both programs, working with religious scholars can be a crucial step in leading a community education program to abandon FGM/C. The Council's research in both countries led to a
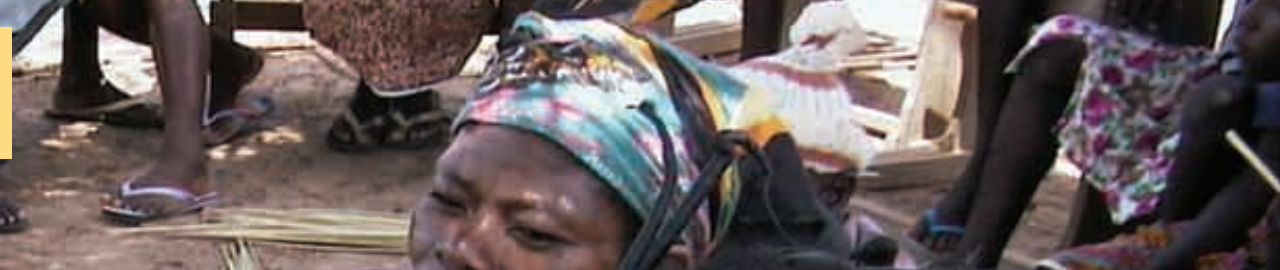
.

new focus on the religious argument for FGM/C and to interventions to delink Islam from $\mathrm{FGM} / \mathrm{C}$.

THE IMPACT Kenyan scholars and imams found no religious justifications for FGM/C and suggested a gradual process to stop the practice. The

Council's technical assistance to the Kenya Council of Imams \& Ulamaa (KCIU) to delink Islam and FGM/C enabled $\mathrm{KCIU}$ to monitor and evaluate its prevention activities. KCIU became part of two prominent organizations: the National Coordinating Agency for Abandonment in Kenya, the national leader on FGM/C; and UNICEF/UNFPA Joint Program, the two UN agencies addressing this issue. Council research and evaluations of prevention programs are informing a national plan of action in Kenya and helped to pass two laws in Kenya's Parliament making it illegal to practice FGM/C.

In Senegal, the percentage of men in the Tostan project with understanding of the dangers of FGM/C increased from $41 \%$ to $92 \%$. The proportion of girls younger than 10 who had not been cut increased from $46 \%$ to $60 \%$ among families participating in the study. Such community-based models are being replicated in several other countries and have been recommended as a best practice by UN organizations.

DONORS US Agency for International Development, Wallace Global Fund 


\section{SAM KALIBALA}

\section{COUNTRY DIRECTOR, KENYA}

Why did you decide to become a physician?

My father was in the health field and wanted me to be a doctor. My mother wanted to be a nurse, but was never able to complete her education. From a young age, my family started calling me "doctor." I liked it and decided to become a surgeon. I received a scholarship to attend Makerere University in Kampala and moved there from my distant rural village. When I learned about the surprisingly high numbers of people with AIDS in Uganda, I felt I had to get involved with AIDS prevention.

Tell us about your role in founding one of the most important HIV prevention organizations in Uganda.

At that time if you had AIDS you were associated with being promiscuous and careless. Most doctors treated AIDS by giving patients curt instructions and pills. My method was different; I counseled people and gave them options. I educated people about the virus and how to live with AIDS. I worked with four other health workers, including one who had AIDS, at a hospital near Kampala. Soon we linked with another group in Kampala, and they helped us to form a branch of TASO: The AIDS Support Organization, the first civil society HIV prevention and care organization in Uganda and Africa.

What has been your most rewarding experience since working at the Population Council?

I am glad to have been part of the Population Council team that introduced projects for preventing the transmission of

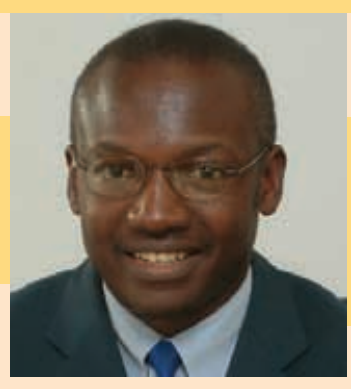

\section{JEFFREY PASSEL}

\section{SENIOR DEMOGRAPHER AT THE} PEW HISPANIC CENTER

Jeff Passel is a nationally renowned expert on immigration patterns in the United States, particularly of the Latino community, and has written extensively on immigration's effect on the country's economy and demography.

After graduating college, I volunteered in Montana with VISTA, a community action agency that provided services to lowincome populations. In the late 1960s, population trends were just becoming a part of people's conversations. I began to appreciate the importance of voluntary family planning and its impact on maternal health and social and economic development in the US and worldwide. This piqued my interest in demography, and after getting my master's in sociology, I applied to become a Population Council fellow. The generosity of the Council's fellowship allowed me to focus on my studies in demography and statistics for my Ph.D. While in my doctoral program, I met John Bongaarts, currently Vice President and Distinguished Scholar at the Council, whose work in demography was and continues to be inspiring. Thanks to the Council's focus on furthering scholarly work in demography, I was able to complete my studies and build relationships in the field.

I have closely followed the Council's work, and I appreciate the importance, breadth, and magnitude of its research to empower women and families to control their fertility. It is vital that the Council continue to develop expertise around the world among both scholars and lay people.

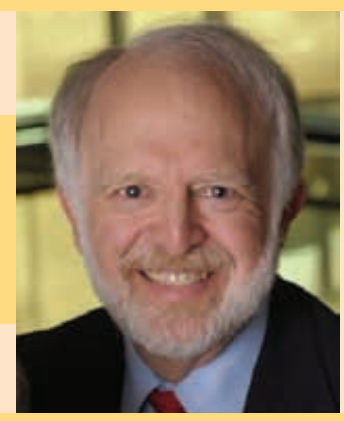

WHY I GIVE TO THE POPULATION COUNCIL

In my work as a demographer, I have collaborated with counterparts in Mexico, a country that has benefited greatly from the work of organizations like the Population Council. The change in Mexican society has been incredibly dramatic. Back when I started this work in 1970, the average woman was having seven children; by 2000 , it was down to roughly 2.2 to 2.4 . We have seen these huge decreases in fertility across all educational and socioeconomic levels.

Allowing couples to decide when to have children is very important. We can point to cases like Mexico where it has made a major difference in improving health and reducing inequality and poverty. Yet there is still tremendous work to be done. The Council's research in educating people and training health workers and scholars is important for many countries and the well-being of the world as a whole.

In many ways I am a beneficiary of the Population Council. It is a pleasure to be a donor and even marginally give back for all that the Council has done, not only for me, but for the many people all over the world who have benefited from their research. 


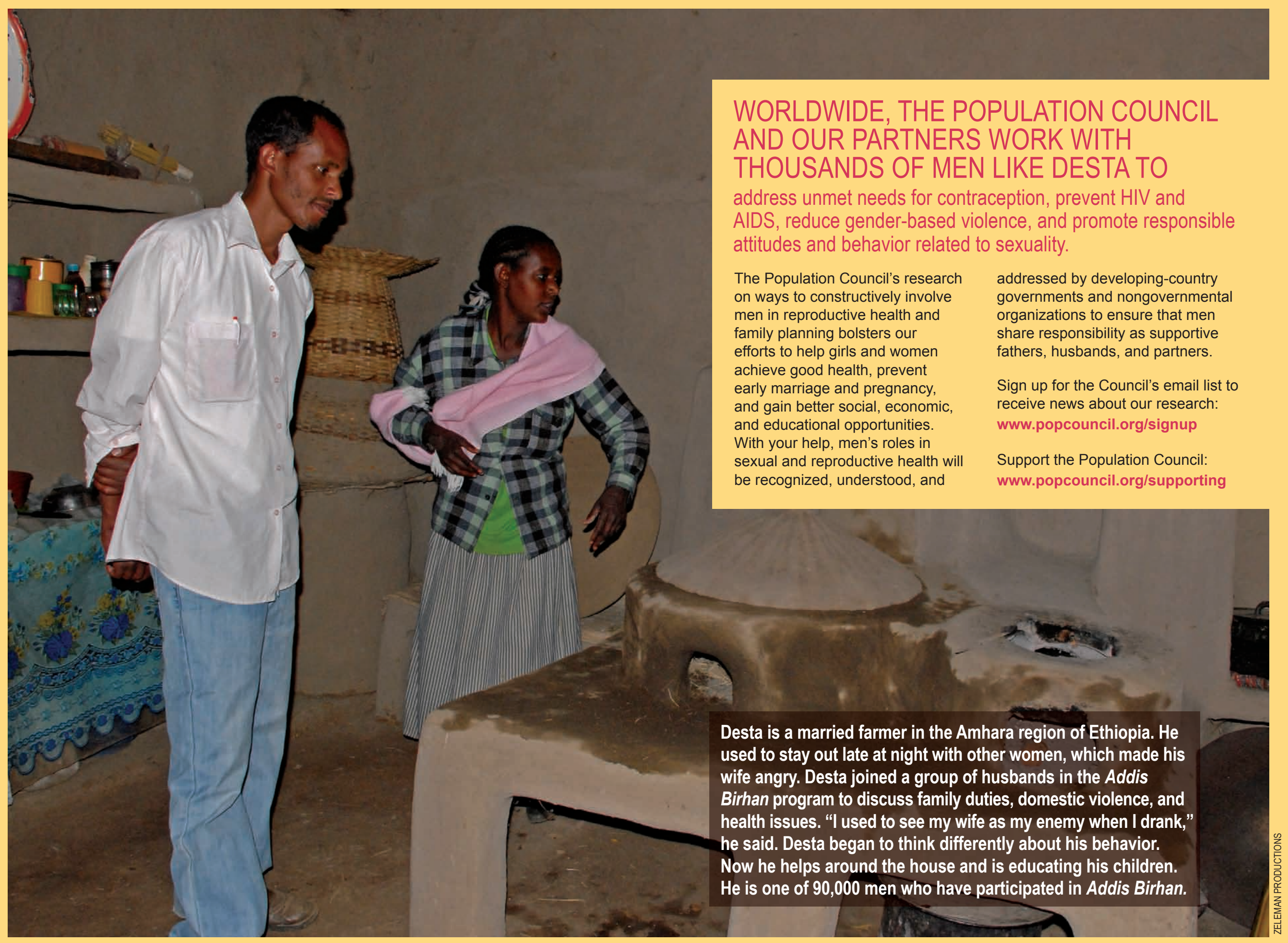




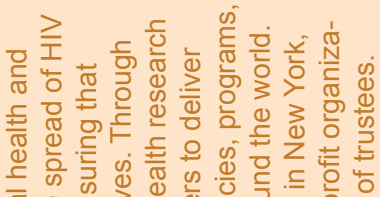

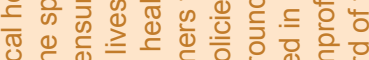

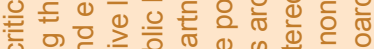

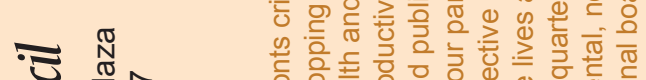

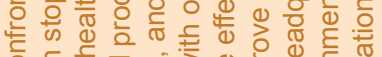

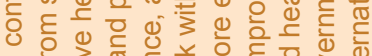

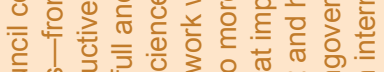

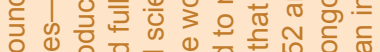

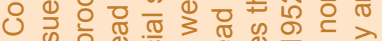
की त ब

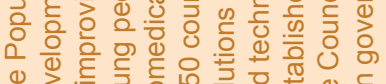

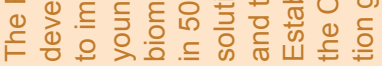
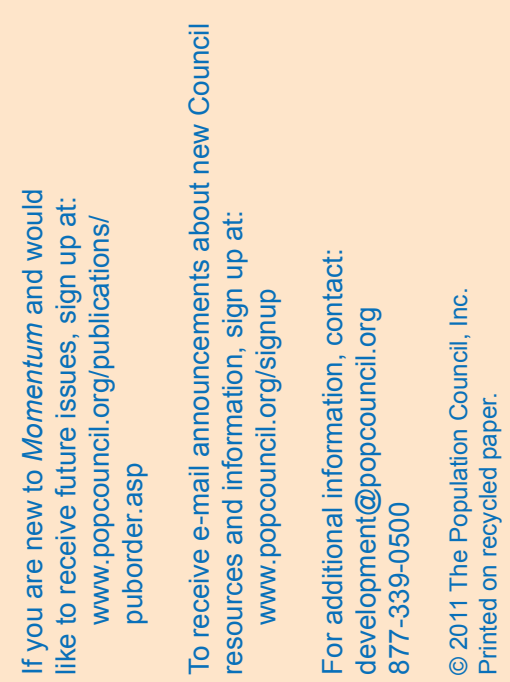